\title{
Sağlık Çalışanlarının Görüş̧leriyle İletişim Çatışmalarının Empati Becerisi Yoluyla Örgütsel Güven Üzerindeki Dolaylı Etkisi: Elazığ Örneği*
}

Indirect Effect of Communication Conflicts With The Opinion of Healthcare Employees on Organizational Trust Through Empathy Skills: The Example of Elazığ

Tuğba Şadiye ÇiTíl ŞAP ${ }^{1}$, Erkan Turan DEMİREL ${ }^{2}$

\section{ÖZ}

$\mathrm{Bu}$ araştırma, "iletişim çatışmaları, örgütsel güven ve empati becerisi” kavramları arasındaki ilişkileri incelemek amacıyla yapılmıştır. $\mathrm{Bu}$ amaç doğrultusunda, Elazığ Merkez İlçe'de yer alan kamuya ait hastanelerin çalışanlarından veri toplanmıştır. Veri toplama tekniği olarak, anketten yararlanılmıştır. Araştırmanın temel bulgusu, "iletişim çatışmalarının empati becerisi yoluyla örgütsel güven üzerinde dolaylı etkiye sahip olduğudur”. Literatürde, araştırmanın değişkenlerinin birlikte incelendiği herhangi bir çalışmaya rastlanamamıştır. Dolayısıyla literatüre özgün katkının sunulduğu düşünülmektedir. Söz konusu değişkenler arasındaki ilişkileri farklı bağlamlar üzerinde ve farklı mesleklerden toplanacak verilerle ele alacak, özgünlük içeren yeni çalışmalara 1şık tutacağı ümit edilmektedir.

Anahtar Kelimeler: İletişim çatışmaları, Empati becerisi, Örgütsel güven.

\begin{abstract}
This research was conducted to examine the relationships between the concepts of "communication conflicts, organizational trust and empathy skills". For this purpose, data was collected from the employees of public hospitals in Elazig Central District. Survey was used as the data collection technique. The main finding of the study is that "communication conflicts have an indirect effect on organizational trust through empathy skills". No study was found in the literature in which the variables of the study were examined together. Therefore, it is thought that an original contribution to the literature was presented. It is hoped that it will address the relationships between these variables in different contexts and with data collected from different professions, and shed light on new studies containing originality.
\end{abstract}

Keywords: Communication conflicts, Empathy skill, Organizational trust.

\footnotetext{
"Bu makale için birinci yazarın tez çalışmasından üretilmiştir. 18. Uluslararası Türk Dünyası Sosyal Bilimler Kongresi’nde (çevrimiçi) sözlü olarak sunulmuştur.

${ }^{1}$ Yüksek Lisans Öğrencisi, Tuğba Şadiye Çi̇TILL ŞAP, Sağlık Yönetimi, Fırat Üniversitesi Sosyal Bilimler Enstitüsü Sağlık Yönetimi Anabilim Dal1, tugba2330@gmail.com, ORCID: 0000-0002-5166-2608

${ }^{2}$ Prof. Dr., Erkan Turan DEMİREL, Yönetim ve Organizasyon, Fırat Üniversitesi İIBF İsletme Bölümü, edemirel@ firat.edu.tr, ORCID: 0000-0001-7754-774X 


\section{GíRiş}

İletişimin, çatışma süreci için oldukça önemli bir role sahip olduğu belirtilmektedir. Diğer bir ifadeyle, iletişim çatışmaların ortaya çıkmasında da yönetilmesinde ve çözülmesinde de etkili olabilmektedir. İletişim süreci, gönderilen mesajların kaynaktan alıcıya iletilmesi şeklinde düşünüldügüünde, örgütsel açısından anlam güçlükleri, yetersiz bilgi alış-verişi, kaynakların yetersizliği ve iletişim kaynaklarının bozukluğu gibi faktörler iletişim çatışmalarına neden olabilmektedir. ${ }^{1}$

Mesaj akışında meydana gelebilecek yanlış anlaşılmalar, gecikmeler, iletilen mesajın açık ve net olmamas1, algilanamamasi, mesajların filtrelenmesi gibi sebeplerle iletişim süreci zarar görebilmektedir. Sürecin zarar görmesi, kişilerin veya grupların farklı davranışlar sergilemelerine ve kararlar almalarına bunlara bağlı olarak da iletişim çatışmalarına sebep olabilmektedir. ${ }^{2}$

İletişim sürecinde kişilerin mesaj alırken, gönderirken ve yorumlarken diğer kişilerin kültürel kategorilerini ve düşünce yapılarını göz ardı etmesi durumlarında, yanlış anlamalar ve yanlış algılamalar meydana gelebilmektedir. Farklılıkların göz ard1 edilmesi olarak da düşünülebilecek bu durum, kişiler arasında iletişim çatışmaları ortaya çıkmaktadır. ${ }^{3}$

Çatışma, genellikle olumsuz bir ifade olarak algılanmaktadır. Çoğunlukla insan hafizasinda negatif anılarla hatırlanan, kederler, hasımlıklar ve aynı zamanda muharebelerin üzücü etkilerini çağrıștıran bir olgu görüntüsü vermektedir. Durum böyleyken, iletişim çatışmalarından kaçınılması mümkün değildir. İletişim çatışmaları, her zaman olumsuz sonuçlara da yol açmamaktadır. Burada yapılması gereken çatışmanın oluşturacağı faydaları kullanmak ve muhtemel olumsuz sonuçları önlemek için çatışmanın pozitif bir bakış açısıyla ve etkili şekilde yönetilmesidir. Bu konuda iletişim becerilerinin önemli katkıları söz konusu olabilmektedir. ${ }^{4}$
Örgütlerde çatışmaları etkili bir biçimde yönetebilen kişilerin en belirgin özelliklerinin iletişim ve liderlik becerileri olduğu belirtilmektedir. $\mathrm{Bu}$ görüşe göre, çatışma yönetimi sürecinde ve çatışmaların işlevsel hale getirilmesinde etkili iletişim öne ç1kmaktadır. ${ }^{5}$

Empatinin karmaşık bir fenomen olduğu ve yaşama becerileri arasında sayıldığ bildirilmektedir. Başkalarının ne hissettiğini, kendisiyle başkaları arasında karışılık olmadan ve mâna birliği sağlama sonucuna yönelik olarak anlama, şeklinde tanımlanan empati ile ilgili tepkiler, yaşamın erken dönemlerinde ortaya çıkmakta ve yaşam boyunca şekillenmeye devam etmektedir. $\mathrm{Bu}$ açıdan empati, uyarlanabilir/şekillenebilir bir yönelimdir. $\mathrm{Bu}$ yönelim ise sosyal etkileşimleri kolaylaştırmaktadır. ${ }^{6,7}$

Araştırmalar, çalışanların empati becerilerinin yükselmesine bağlı olarak, hizmet alanlarla olumlu etkileşim kurabildiklerini ve tükenmişlik gibi olumsuz yük oluşturacak etkenlerden korunduklarını göstermektedir. ${ }^{6}$

Empatinin birçok tanımı arasında Rogers (1983) tarafindan önerilen tanım, en yaygın kullanılan tanımdır. Bu tanım empatiyi, "yanınızda olan kişinin duygularını, düşüncelerini ve hissiyatını doğru anlamayı, bunu o'na aktarmayı içeren hissi süreç" olarak ifade etmektedir. ${ }^{8}$

İnsanın var olduğu yerlerde çatışmalar da kaçınılmaz olarak yer almaktadır. Bireylerin çatışmalara karşı gösterdikleri tepkiler de farklılaşmaktadır. Burada en önemli olan husus çatışmayla başa çıkabilmek ve yapıcı çözüm yollarına ulaşabilmektir. Yapıcı çözüm yolları arasında, empati ve iletişim becerileri önemli etkiye sahip olarak kabul edilmektedir. Birbirlerini tamamlayan bu iki beceri, çatışmanın yıkıcı sonuçlarını önleyebilmektedir. ${ }^{8,9}$

Sağlık çalışanları, farklı açılardan siniflandirilabilecek hedef kitleye hizmet sunmaktadırlar. Kültür başta olmak üzere 
farklılıkları dikkate alarak, nitelikli hizmet sunmak, empati becerisi ve iletişim becerisi gerektirmektedir. Diğer bir ifadeyle empatinin ana unsurunun kültürel farkl1lıklara sayg1 duymak ve duyarlı olmaktır. Bireylerin farklı kültürlere olumlu davranışlar sergileyebilmeleri için empati becerisine sahip olmaları ve bu beceriyi pratikte uygulayabilmeleri gerekmektedir. ${ }^{10}$, 11

Empati, giderek daha fazla öğrenilebilir bir beceri olarak tanımlanmakta ve sağlik hizmetleri için profesyonellik gerekliliklerine dâhil edilmektedir. Profesyonelliğin bir parçası olarak empati sergilemek, hasta sonuçlarının iyileşmesine, sağlık çalışanları arasında tükenmişliğin azalmasına ve iş tatmininin artmasına neden olmaktadır. ${ }^{12}$

Empatiyi sağlık çalışanları açısından bir dizi beceri olarak kavramsallaştırmak gerektiğinde şu çerçeve ortaya çıkmaktadır: Bir sağlık çalışanının hastayı anlaması; bunu sözlü ve sözsüz iletișiom süreçlerine yansıtması ve terapötik bir ortamın biçimlendirilmedir. Terapötik ortamın belirleyicileri ise bireylerin kendilerini tehdit altında hissetmedikleri, kendilerini içtenlikle ifade edebildikleri, bireysel ve sosyal bağlamda destekleyici, geliştirici ve rahatlatıcı koşullar olarak sayılmaktadır. Bu açıdan empatinin şu beş temayı da içerdiği söylenmektedir: adlandırma, anlama, saygı duyma, destekleme ve ifade edilen duyguları keşfetme. ${ }^{7,13}$

Bireyler arası güven, bir toplulukta kişilerin kendini karşısındakinin yerine koymasını, yani empatiyi içermektedir. Güven sadece insanlar birbirlerini anladıklarında gerçekleşebilecek bir olgudur. Bir insanın başka bir insanın hislerini, hayata bakışını ve fikirlerini anlayabilmesi şeklinde yorumlanan empati, güvenin bir ön şart1 olarak dile getirilmektedir. ${ }^{14}$

Örgütsel güven, örgütün (yöneticilerin, çalışma arkadaşlarının) çalışanlara sağladığı itimat duygusu olarak ifade edilmektedir. Hem bireysel açıdan hem de toplumsal açıdan güven, daha çok karşı taraftan beklenti yönlü ve etkileşim koşullarına göre öne çıkmaktadır. Bu bakış açısıyla güven, tarafların birbirinden zarar görmeyeceklerine inanmaları veya karşı tarafin tehlike oluşturmayacağına olan itimat şeklinde ifade edilmektedir. ${ }^{15}$

Aynı zamanda güven, kırılgan bir yapıdadır. Genel olarak güven, emek isteyen ve uzun vadede oluşan bir olgu iken, dikkat edilmediği takdirde çabuk kaybedilebilecek bir yapıda olduğu dile getirilmektedir. Güven, aynı zamanda bir örgütün karnesi gibi denetlenebilen bir unsur olarak da ifade edilmektedir. ${ }^{16}$

Örgütsel güven, kişilerin örgütsel destekle ilgili algılarına dayanarak örgüt yönetimindeki kişilerin güvenilir olacaklarına, verdikleri sözleri tutacaklarına ve bu konudaki tutarlilik sergileyeceklerine ilişkin umutları şeklinde tanımlanmıştır. ${ }^{17}$ Örgütün paydaşları arasında yayılan itimat duygusunun, örgüt içerisinde genelleşmesi, örgütsel güvenin varlığına işaret etmektedir. ${ }^{18}$ Örgütsel güven kavramı, örgütün bir bütün olarak çalışanlara zarar vermekten kaçınacağına ve yarar sağlayacağına itimat edilmesi, bu düşünceye uygun davranışların süreklilik taşıdığına inanılması anlamını taşımaktadır. ${ }^{19}$

Örgütsel güvenin; örgüte, yöneticiye ve çalışma arkadaşlarına güven şeklinde üç boyutunun olduğu ifade edilmektedir. Çalışanlar, bütün bu boyutlara güvendiklerinde; örgütsel amaçlar için daha çok emek harcamakta, motivasyonları artmakta ve örgüte olan aidiyet duyguları güçlenmektedir. ${ }^{20}$

Örgütsel güvenin düşük seviyede olması, iletişim süreçlerinin etkililiğini azaltmaktadır. $\mathrm{Bu}$ durumun olas1 sonuçlarından birisi de iletişim çatışmalarının yaşanmasıdır. ${ }^{21}$ Sağlık hizmetleri açısından yaklaşıldığında, örgütsel güvenin, işbirliği ve iletişimde etkililik ile kaliteli hizmet sunumu için temel unsurlardan olduğu söylenmektedir. ${ }^{22}$ Sağlık çalışanları, hizmet sunumuna ilişkin teknik yeteneğe, iletişim becerilerine ve bilgi yeterliliğine sahiplerse; etik ilkelere uyuyorlarsa, mahremiyete özen gösteriyorlarsa ve muhataplarını önemsiyor ve sayg1 gösteriyorlarsa ortamda güven tesis edilmiş demektir. $^{23}$ 
Örgütsel güvenin düşük olduğu ortamlarda, örgütsel çatışmalar yoğunlaşmaktadır. Böyle durumlarda, çalışanların örgütsel amaçları benimseme düzeyleri düşerken; devamsızlık oranları, performansları ile verimlilikleri de düşmektedir. ${ }^{24}$

Örgütsel amaçlara erişilebilmesi için ekip çalışması, ekip çalışması için de örgüte, yöneticilere ve çalışma arkadaşlarına, gerekmektedir. Örgütsel güvenin hâkim olduğu çalışma ortamlarında çalışanların performansları artmakta, örgütsel bağll lık ve örgütsel vatandaşlık davranışları gelişmekte, iş tatmini düzeyleri yükselmekte nihai olarak ise çatışmalar azalmaktadır Bütün bu kazanımların temelinde de örgütsel iletişimin sağlıklı olması bulunmaktadır. ${ }^{25}$

\section{MATERYAL VE METOT}

\section{Araştırmanın Yöntemi}

Araştırma, nicel yönelimli bir araştırma şeklinde gerçekleştirilmiştir. Nicel yönelimli araştırmalar, sayısal veriler kullanılarak, genellenebilir sonuçlar üretmeyi hedefleyen araştırmalardır. Görgül nitelikli ve tümdengelim yaklaşımının benimsendiği nicel araştırmalarda, gözlem ve ölçümlerin tekrarlanabilirliği öne çıkmaktadır. ${ }^{26}$

Araştırmanın deseni ise nicel araştırma desenlerinden nedensel tarama araştırmasıdır. Genel olarak tarama araştırması, bireylerin belirli konulardaki tutum, davranış görüş, beklenti ve özelliklerini tespit etmek için yapılan araştırma anlamındadır. Başlıca veri toplama tekniği anket yöntemidir. Anketlerin içeriği araştırmacıların ve araştırmanın amaçlarına göre belirlenir. Tarama araştırmaları, geniş örneklem kitlelerine ulaşmak, doğru örneklem tekniği ve sağlam bir ölçek ile evreni tanımlayan genellenmiş ve güvenli sonuçlar üretmek, birden fazla değişken arasındaki ilişkiyi aynı anda test etmek gibi üstünlükleri söz konusudur. ${ }^{26}$

Nedensel tarama araştırması ise bir ya da birden fazla bağımlı değişken üzerinde etkisi olan bağımsız değişkenin veya değişkenlerin tespit edilmeye çalışıldığ 1 araştırmalar anlamını içermektedir. $\mathrm{Bu}$ araştırma deseninde, bağımlı değişkenleri yordayan öncül değişkenler ile bir değişkenin olası sonuçları incelenmeye çalışılır. Nedensel tarama araştırmalarında deneysel araştırmalar gibi değişkenlere müdahale söz konusu olmayı; anket yoluyla katılımcilardan veriler toplanmakta ve analiz edilerek ilişkiler ortaya konulmaya çalışılmaktadır.
Nedensellik için ise sebebin (bağımsız değişken) sonuçtan (bağımlı değişken) önce gelmesi; sebep değiştikçe sonucun da değişmesi, sahte nedensellik olmaması ve nedenselliğin mantığa ya da kurama dayanan bir açıklamasının olması gereklidir. ${ }^{26}$

\section{Araştırma Modeli}

Literatürden erişilebilen bulguların temelinde oluşturulan araştırma modeli, aşağıda paylaşılmaktadır:

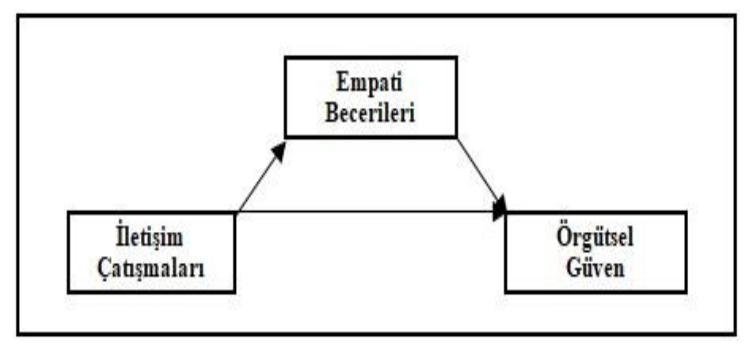

Şekil 1. Araştırma Modeli

Yukarıda ifade edilen model ve literatür bulguları açısından araştırma hipotezleri şöylece belirlenmiştir:

H1: İletişim çatışmaları ile empati becerileri arasında negatif ilişki vardır.

H2: Örgütsel güven ile empati becerileri arasında pozitif ilişki vardır.

\section{$H_{3:}$ Illetişim çatışmaları $(X)$ ile örgütsel güven ilişkisinde (Y) empati becerileri (M) aracı değişken rolü oynamaktadır.}

Modelden ve hipotezlerden anlaşılacağ 1 üzere bağımsız değişkenle bağımlı değişken arasındaki ilişkide aracılık etkisinin (rolünün) varlı̆̆ı test edilecektir. Literatür bulguları bu yönde olup; söz konusu çalışma 
ile iddiaya $\left(\mathbf{H}_{1}, \mathbf{H}_{2}\right.$ ve $\left.\mathbf{H}_{3}\right)$ görgül destek oluşturulması hedeflenmektedir.

Aracılık etkisinin varlığı, aracı değişkenin varlığına bağlıdır. Aracı değişken ise bağımsız değişkenin etkisini bağımlı değişkene iletmektedir. Bir diğer ifade ile aracı değişkenin, bu iki değişken arasında bağlantı mekanizması (köprü) gibi çalıştığı söylenebilir. Aracı değişkenin etkisi, domino taşları metaforu ile de açıklanabilir: Domino taşına benzetilen aracı değişken; bağımsız değişkenden etkilenmesinden sonraki adımda bağımlı değişkeni etkilemektedir. ${ }^{26}$

\section{Evren ve Örneklem}

Araştırma evreni olarak Elazı̆̆ il merkezinde bulunan kamuya (Sağlık Bakanlığı ve Fırat Üniversitesi) ve özel sektöre ait hastanelerin çalışanları belirlenmiştir. Ancak, özel hastanelerden izin alınamamış olup; kamuya ait hastanelerin çalışanlarından anket yoluyla veriler toplanmıştır. Söz konusu kurumların çalışanlarından araştırmamıza katılmak için gönüllü olan ve zaman ayıranlarla çalışılmıştır. Verilerin toplandığı Ocak-Şubat 2020 dönemi için izin alınan hastanelerin toplam çalışan sayısı 3712 'dir.

Evren büyüklügü 3712 olarak alındığında minimum örneklem büyüklüğü aşağıdaki formüle göre 349 olarak hesaplanmıştır. Bu büyüklüğün (349 ve üzeri), örneklemin evreni temsil gücünün $\% 95$ güven aralığında yeterli olduğu söylenebilir. ${ }^{27}$ Araştırmada değerlendirmeye alınan örneklem büyüklüğü ise 352 olmuştur.

$$
\mathrm{n}=\left(\mathrm{N}_{\mathrm{xt}} \mathrm{t}^{2} \mathrm{x} \times \mathrm{xq}\right) /\left[\left((\mathrm{N}-1) \times \mathrm{d}^{2}\right)+\left(\mathrm{t}^{2}{ }^{\mathrm{x}} \mathrm{x} \mathrm{q}\right)\right]
$$

$N$ : evren büyüklüğü (3712); $t$ : $t$ tablo değeri (1,96); $p$ : gerçekleşme olasilığ ( $(\underline{0,5}) ; q$ : gerçekleşmeme olasiliğ $(\underline{0,5}) ; d$ : kabul edilen örnekleme hatast $(\underline{0,05})$ alındığında $n: 349$ hesaplanmiştır.

\section{Veri Toplama ve Analiz Teknikleri}

Veril toplamada anket tekniğinden yararlanılmıştır. Anket, belirli bir konuda ve sınırlandırılmış sorular aracılığıyla, katılımcıların duygularını, düşüncelerini, tutumlarını ve davranışlarını tespit etmeyi sağlamaktadır. Anket, veri toplamada sıklıkla karşılaşılan teknikler arasındadır. Anket yoluyla elde edilen verilerin, analizlerinin yapılması diğer veri toplama tekniklerine göre daha kolaydır. ${ }^{26}$

$\mathrm{Bu}$ çalışmada kullanılmış olan anket formu dört kısımdan oluşmaktadır. İlk kısımda 9 ifade içeren "iletişim çatışmaları" ölçeği yer almaktadır. ${ }^{28}$ Özgün çalışmada Cronbach's Alpha değeri 0,85 ve açıklanan varyans ise $\% 56$ olarak tespit edilmiştir. Ölçek, 9 maddeden ve "iş birliğinden kaçınma ve güven eksikliği, güven eksikliğine tepki" isimlerini taşıyan 2 boyuttan oluşmaktadır. Ölçek maddeleri, 5'li Likert tipine göre derecelendirilmiş olup, ters puanlanan madde yer almamaktadır.

Anketin ikinci kısmında Dökmen'e ait olan "empati becerileri" ölçeği yer almaktadır. Sözü edilen çalışmada Cronbach's Alpha değeri 0,80 olarak tespit hesaplanmıştır. Ölçekte, 6 kısa hikâye ve bunların her biriyle ilgili 12'şer tepki yer almaktadır. En düşük 62 puan ve en yükssek 219 puan alınabilmektedir. $62-124,8$ puan aras1 zayif empati becerisini, 124,8-156,2 puan aras1 vasat empati becerisini, 156,2-219 puan arası ise güçlü empati becerisini göstermektedir. ${ }^{29}$

Anketin üçüncü kısmında Tokgöz ve Seymen tarafindan Türkçe geçerlemesi yapılan "örgütsel güven ölçeği" yer almaktadır. Geçerleme çalışmasında Cronbach's Alpha değeri 0,95 ve açıklanan varyans \%73,2 olarak tespit edilmiştir. Ölçek, 28 maddeden ve "örgüte güven, yöneticiye güven, çalışma arkadaşlarına güven" isimlerini taşıyan 3 boyuttan meydana gelmektedir. Ölçek maddelerinin derecelendirilmesinde, 5'li Likert tipi temel alınmıştır. Ölçeğin ters puanlanan maddesi yoktur. ${ }^{30}$

Anketin son k1smı ise demografik özellikleri belirlemek amaçlı soruları içermektedir.

Araştırma hipotezlerinin sınanması için de regresyon ve aracilı analizlerinden yararlanılmıştır. Analizler için Fırat Üniversitesi tarafından lisanslanmış olan SPSS programı kullanılmıştır. 


\section{Araştırmanın Etik Yönü}

$\mathrm{Bu}$ araştırma, Fırat Üniversitesi Sosyal ve Beşeri Bilimler Araştırmaları Etik Kurulu'nun 17.10.2019 tarih ve 36/1 sayılı kararıyla etik açıdan uygun bulunmuştur.

Furat Üniversitesi Hastanesi Başhekimliği 06.11.2019 tarih ve 358108 sayılı yazısıyla bu araştırma için veri toplanmasına izin vermiştir.

Fırat Üniversitesi Diş Hekimliği Fakültesi Uygulama ve Araştırma Merkezi Başhekimliği 05.12.2019 tarih ve 363733 sayılı yazısıyla bu araştırma için veri toplanmasına izin vermiștir.

Elazı ̆ Fethi Sekin Sehir Hastanesi Başhekimliği ile 25.10.2019 tarihinde imzalanan protokol ile bu araştırma için veri toplanmasına izin alınmıștır.

$\mathrm{Bu}$ araştırma için herhangi bir kişi ya da kuruluştan maddi destek alınmamıştır.

\section{Araștırmanın Kısıtlılıkları}

$\mathrm{Bu}$ çalışmanın bazı sinırlılıkları bulunmaktadır. Araştırmanın bir sınırlılığı, araştırma örneklemi ve veri toplama işleminin Elazı ̆̆ Merkez'de bulunan üç kamu hastanesiyle sinırlı kalmasıdır. Araştırmamızda kurum izni alınamayan özel sağlık kuruluşları, gönüllülük kapsamında veri toplama işleminde çalışma kapsamına dâhil olmak istemeyen ve zaman kısıtlığı ya da iş yoğunluğu nedeniyle araştırma kapsamına katılım sağlayamayan sağlik profesyonelleri bulunmaktadır. $\mathrm{Bu}$ nedenle özel sağlık kuruluşlarından elde edilemeyen veriler ve araştırma kapsamına zaman kısıtlığı nedeniyle dâhil edilemeyen sağlık profesyonelleri araştırma sonuçlarını değiştirebileceği düşünülmektedir. $\mathrm{Bu}$ bağlamda bu araştırmadan elde edilen veriler, araştırma örneklemini temsil etmektedir ve bu nedenle evrene genellenemez. Öte yandan bu araştırmanın bir diğer sinırlılığ katılımcıların anket formlarına verdiği cevapların doğruluğuyla sınırlı kalmaktadır.

\section{BULGULAR VE TARTIŞMA}

\section{Ölçeklerin Geçerlilik ve Güvenilirlik Bulguları}

Örgütsel güven ölçeği, faktör analizi sonuçları, ölçek maddelerinin üç boyutta kümeleştiğini (1:yöneticiye güven, 2:çalışma arkadaşlarına güven) göstermektedir. $\mathrm{Bu}$ yapının açıklayabildiği toplam varyans, $\% 70,16$ 'dır. Ölçeğin $(0,964)$ ve boyutlarının cronbach alpha katsayıları da (sirasiyla: $0,924 / 0,959$ / 0,945) yüksek düzeydedir.

İletişim çatışmaları ölçeği, faktör analizi sonuçları, ölçek maddelerinin iki boyutta kümeleștiğini (1:bireyler arasında işbirliğinden kaçınma ve güven eksikliği, 2:birey ve işletme arası güven eksikliğinin sonucu oluşan tepkiler) göstermektedir. Bu iki faktörlü yap1, toplam varyansın \%56,60'ını açıklamaktadır. Ölçeğin tümünün $(0,840)$ ve boyutlarının cronbach alpha katsayıları da (sirasiyla: 0,747 / 0,756) yüksek düzeydedir.

Empatik eğilimin ölçeğinin geçerliliğinin ortaya konulması için ölçüt geçerliliği sınanmıştır. Bunun için empatik eğilim ve empati becerileriyle ilişkili oldukları bildirilmiş olan duygusal zekâ (Balat vd., 2014) ve iletişim becerileri (Baltac1, 2016) kavramlarıyla korelasyon incelenmiştir. Araştırmaya katılanlardan rastgele seçilen 100 kişiye duygusal zekâ (Aslan ve Erkuş, 2008) ve iletişim becerileri (Owen ve Bugay, 2014) ölçekleri de uygulanmıştır. Empati becerisi ölçeğinin cronbach alpha katsayısı 0,847 olarak hesaplanmıştır. Empati becerisi ile duygusal zeka arasindaki korelasyon 0,530 iken; empati becerileri ile iletişim becerileri arasındaki korelasyon ise 0,588 düzeyindedir. Her iki korelasyon katsayısı da 0.01 düzeyinde anlamlı ve pozitif yönlüdür. Buna göre empati becerisi ölçeğinin ölçüt geçerliliği koşullarını sağladığ1 görülmüştür. ${ }^{31,32}$

\section{Örneklemin Demografik Bilgileri}

Katılımcıların \%54'lik kısmı 21-30 yaş aralığındadır. Cinsiyet değișkeni açısından 
katılımcıların \%59,7'sini kadınlar temsil etmektedir. Katılımcıların \%54,5'lik kısmı evlidir. Katılımcıların \%38,9'nun gelir durumu 4000-6000 TL arasindadir. Katılımcıların \%44'lük kısmını hemşireler oluşturmaktadır. Katılımcıların birimi \%36,6'l1k kısmı hastanelerin dahili tıp bilimleriyle ilgili birimlerinde çalışmaktadır. Katılımcıların meslekte geçirilen süre bakımından \%39,2'lik kısmının hizmet süresi 5 yıl ve altındadır. Katılımcıların şuan ki iş yerinde geçirilen süre bakımından \%65.6's1 5 y1l ve altındadır. Katılımciların \%51,1'i açısından iş yoğunluğu çok yüksektir. Katılımcıların \%42,9'u işlerinin zorluk derecesini zor, yine katılımciların $\% 41,8$ ' ise işlerinin risk derecesini çok yüksek olarak tanımlamaktadır.

\section{Hipotez Testleri}

Aracılık etkisi, çağdaş yaklaşım ile analiz edilmiş olup; işlemler SPSS Macro aracılığıyla yapılmıştır. Aracılık testiyle ilgili çağdaş yaklaşım adımları şu şekildedir: ${ }^{33}$ $\checkmark$ X'in $\mathrm{Y}$ üzerindeki etkisi test edilir (c yolu). İdeal olan, c yolunun anlaml çıkmasıdır. Ancak, aksi durum, aracılık etkisinin olmadığı anlamına gelmez.

$\checkmark$ X'in M üzerindeki etkisi test edilir (a yolu). İdeal olan, a yolunun anlamlı çıkmasıdır. Ancak, aksi durum, aracılık etkisinin olmadığı anlamına gelmez.

$\checkmark$ M'nin $\mathrm{Y}$ üzerindeki etkisi test edilir (b yolu). Bu test için, $\mathrm{X}$ ile M'nin birlikte regresyona dahil edilmesi gereklidir.

$\checkmark$ X'in M aracılığıyla Y üzerindeki dolaylı etkisi (a.b), bootsrapt tekniği ile test edilir. Aracılık etkisinden söz edebilmek için dolaylı etkiyle ilgili bootsratpt analizi sonucunun anlamlı çıkması ve \%95 güven aralıklarının 0 (sıfır) değerini içermemesi gerekir.

$\checkmark$ Aracılık etkisinin büyüklüğü için " $\mathrm{K}$ " yorumlanır. $\mathrm{K}^{2}=.01$ 'e yakınsa düşük etki; $\mathrm{K}^{2}=.09$ 'a yakınsa orta etki ve $\mathrm{K}^{2}=.25$ 'e yakınsa yüksek etki söz konusudur.

(Bu yollar, Şekil 2'de gösterilmektedir.)

Tablo 1. Aracılık Testi Bulguları

\begin{tabular}{|c|c|c|c|c|c|c|}
\hline & \multicolumn{6}{|c|}{ Sonuç Değișkenleri } \\
\hline & \multicolumn{3}{|c|}{$\mathbf{M}$} & \multicolumn{3}{|c|}{$\mathbf{Y}$} \\
\hline $\begin{array}{c}\text { Tahmin } \\
\text { Değișkenleri }\end{array}$ & & b & S.H. & & b & S.H. \\
\hline $\mathbf{X}$ & $\mathbf{a}$ & $4,1859^{*}$ & , 1182 & c' & ,0503 & , 1296 \\
\hline $\mathbf{M}$ & - & - & - & B &, $6043^{* *}$ & 0260 \\
\hline \multirow[t]{3}{*}{ Sabit } & $\dot{\mathbf{I}}_{\mathbf{M}}$ & $13,519^{*}$ & 2,5475 & $\dot{\mathbf{I}}_{\mathbf{Y}}$ & $5,2533^{* *}$ & 1,5533 \\
\hline & \multicolumn{3}{|c|}{$\mathbf{R}^{2}=, 4102$} & \multicolumn{3}{|c|}{$\mathbf{R}^{2}=, 4501$} \\
\hline & \multicolumn{3}{|c|}{$\mathbf{F}(\mathbf{1} ; \mathbf{5 2 1})=1253,3998 ; \mathbf{p}=, 0000$} & \multicolumn{3}{|c|}{$\mathbf{F}(\mathbf{2} ; \mathbf{5 2 0})=686,0625 ; \mathbf{p}=, 0000$} \\
\hline
\end{tabular}

Yukarıdaki Tablo 1'de ve aşağıdaki Şekil 2'de aktarılan aracılık testi bulguları; "c yolunun anlamlı olduğunu"; "a yolunun anlamlı olduğunu"; "b yolunun anlamlı olduğunu" ve "dolaylı etkinin (a.b) anlamlı olduğunu göstermektedir. Dolaylı etkinin $\% 95$ güven aralıkları da "0" değerini içermemektedir. $\mathrm{Bu}$ bulgular 1şı̆̆ğnda, araştırmanın temel hipotezinin $\left(\mathrm{H}_{3}\right.$ : İletişim çatışmaları ile örgütsel güven ilişkisinde empati becerileri aracı değişken rolü oynamaktadır.) desteklendiği tespit edilmiştir. İletişim çatışmalarının örgütsel güven üzerindeki toplam etkisi \%20,06 iken; bu etkinin \%5,03'ünü doğrudan etki ve \%15,23'ünü dolaylı etki oluşturmaktadır. Tespit edilen aracılık etkisinin, orta düzeyde olduğu, analiz sonucu ulaşılan diğer bir bulgudur. İletişim Çatışmaları, örgütsel güven etkisini, empati becerisi anlamlı bir şekilde taşımaktadır. Diğer bir ifadeyle, İletişim çatışmaları, örgütsel güven oluşmasıyla empati becerisinin daha güçlü sonuçlar üretmesine katkı sağlamaktadır. 


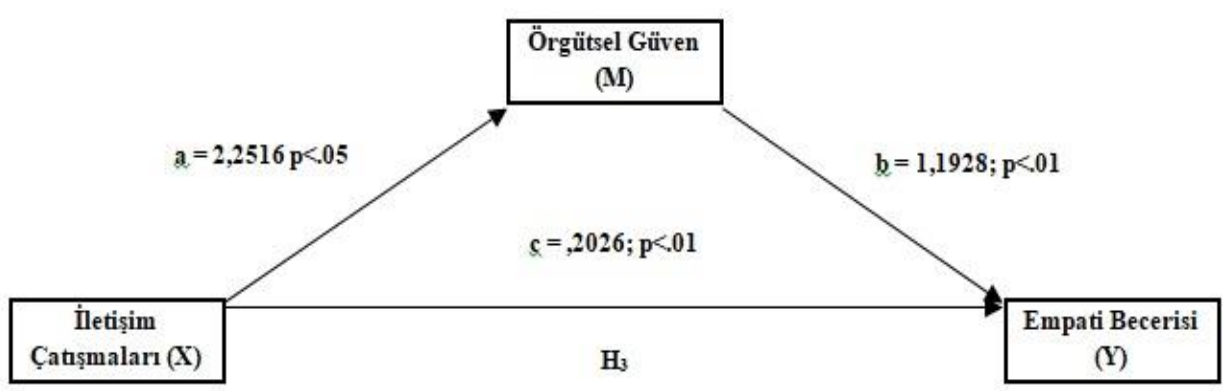

Doğrudan etki $\left(c^{\prime}\right)=, 0503 ; p>.05$

Dolayll etki $=, 1523 ; \% 95 ; p<.01 ;$ CI [,2422; ,8252]

$K^{2}=0,0823$ (orta etki)

\section{Şekil 2. İletişim Çatışmaları, Örgütsel Güven ve Empati Becerisi Aracılık Test Bulguları}

Regresyon analizleri yapılarak araştırmanın diğer hipotezleri $\left(\mathrm{H}_{1}\right.$ ve $\left.\mathrm{H}_{2}\right)$ sınanmıştır. Analiz sonuçları, aşağıdaki Tablo 2'de aktarılmaktadır.

Model 1'e ilişkin bulgular incelendiğinde $\mathrm{H}_{1}$ 'in (İletişim çatışmaları ile empati becerileri arasında negatif yönlü bir ilişki vardır) desteklendiği anlaşılmaktadır. Empati becerileri ile iletişim çatışmaları arasındaki ilişkinin yönü negatif yolup, orta düzeydedir.
Model 2'ye ilişkin bulgular incelendiğinde örgütsel güven ile iletişim çatışmaları arasındaki ilişkinin negatif yönde ve orta düzeyde olduğu anlaşılmaktadır.

Model 3'e ilişkin bulgular incelendiğinde $\mathrm{H}_{2}$ 'nin (Örgütsel güven ile empati becerileri arasında pozitif yönlü bir ilişki vardır) hipotezinin desteklendiği anlaşılmaktadır. Örgütsel güven ile empati becerisi arasında pozitif yönlü ve orta düzeyde ilişki bulunmaktadır.

Tablo 2. Regresyon Analizleri

\begin{tabular}{|c|c|c|c|c|c|c|}
\hline & Değişken & B & $\begin{array}{c}\text { Standart } \\
\text { Hata }_{B}\end{array}$ & $\boldsymbol{\beta}$ & $\mathbf{T}$ & $\mathbf{p}$ \\
\hline \multirow{4}{*}{ Model 1} & Sabit & 13,279 & 2,533 & & 5,243 & 000 \\
\hline & İletişim çatışmaları & $-4,195$ &, 118 &,- 458 & 35,619 &, 000 \\
\hline & \multicolumn{6}{|c|}{$\mathbf{R}=-0,458 \mathbf{R}^{2}=0,210 \mathbf{F}_{(\mathbf{1}, \mathbf{5 2 3})}=1268,743 \mathbf{p}=, 000$} \\
\hline & \multicolumn{6}{|c|}{ Empati becerisi $=13,279-4,195 *$ İletişim çatışmaları } \\
\hline \multirow{4}{*}{ Model 2} & Sabit & 13,249 & 2,145 & & 6,177 & 000 \\
\hline & İletişim çatışmaları & $-2,033$ &, 100 &,- 525 & 20,385 &, 000 \\
\hline & \multicolumn{6}{|c|}{$\mathbf{R}=-0,525 \mathbf{R}^{\mathbf{2}}=0,276 \mathbf{F}_{(\mathbf{1}, \mathbf{5 2 3})}=415,546 \mathbf{p}=, 000$} \\
\hline & \multicolumn{6}{|c|}{ Örgütsel güven $=13,249-2,033 *$ Iletişim çatışmaları } \\
\hline \multirow{4}{*}{ Model 3} & Sabit & 3,746 & 1,515 & & 2,472 & ,014 \\
\hline & Empati becerisi &, 520 &, 014 & ,469 & 36,568 &, 000 \\
\hline & \multicolumn{6}{|c|}{$\mathbf{R}=0,469 \mathbf{R}^{\mathbf{2}}=0,220 \mathbf{F}_{(\mathbf{1}, \mathbf{5 2 3})}=1337,192 \mathbf{p}=, 000$} \\
\hline & \multicolumn{6}{|c|}{ Örgütsel güven $=3,746+0,520 *$ Empati becerisi } \\
\hline
\end{tabular}

Dökmen, İnsanın yaşamını sürdürebilmek için bilgi edinmeye ve yalnız kalmamaya ihtiyaç duyduğunu belirtmektedir. $\mathrm{Bu}$ iki istek (ihtiyaç) ise iletişimin niteliğini belirlemektedir. $\mathrm{Bu}$ bağlamda, çatışmalı iletişim, çatışmasız iletişim ve empatik iletişim şeklinde isimlendirilen üç iletişim türünden söz edilmektedir. Çatışmalı iletişim, her iki ihtiyaca da engel olmaktadır. Çatışmasız iletişim bilgi paylaşımını sağlamaktayken, yalnızlığa çoğu zaman engel olamamaktadır. Empatik iletişim de bilgi paylaşımı ve yalnız kalmama açısından sorun çıkmamaktadır. Durum böyle olunca, empati becerilerinin çatışmalara engel olma, yalnız kalmayı engelleme ve güven tesis 
etme açısından taşıdığı rolün önemi ortaya çıkmaktadır. Çalışmanın bulguları ise bu açıdan bakıldığında ampirik kanıt niteliği taşımaktadır. ${ }^{39}$

Araştırma bulguları hipotezlerin desteklendiğine işaret etmektedir. $\left(\mathrm{H}_{1}\right.$ : İletişim çatışmaları ile empati becerileri arasında negatif ilişki vardır. $\mathrm{H}_{2}$ : Örgütsel güven ile empati becerileri arasında pozitif iliş̧i vardır.). Erişilebilen literatür bulguları, araştırmanın bulgularıyla uyum sergilemektedir ${ }^{8-11,21,34-38}$. $\quad \mathrm{Bu}$ açıdan bakıldığında, literatüre özgün bir katkının sunulabildiği ve "iletişim çatışmaları, örgütsel güven ve empati becerisi" kavramları arasındaki ilişkileri farklı açılardan ele alacak ilgili disiplinlere özgü yeni çalışmalara 1şık tutacağı ifade edilebilir.

\section{SONUÇ VE ÖNERILER}

Araştırma bulguları, beklentilerle uyumlu şekilde ortaya çıkmıştır. Hipotezlerin tamamının desteklendiği görülmektedir. Literatürde, temel hipotezin (aracilık modeli) sınandığı bir çalışmaya rastlanamamıştır. Bu açıdan, çalışmanın literatüre özgün bir katkı sunduğu düşünülmektedir.

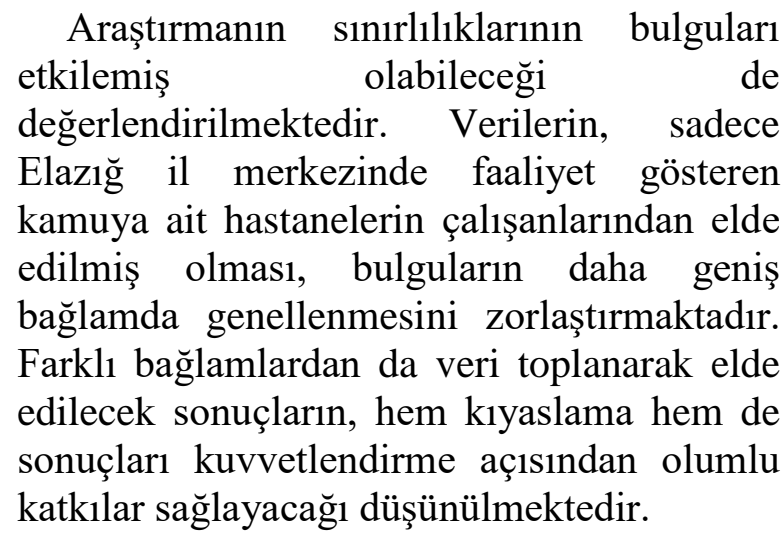

Araştırma veri toplanabilmesi için özel sektöre ait sağlık kuruluşlarından izin alınamamıştır. Özel hastanelerde ön planda tutulan olan ticari kaygının, kurumsal stratejiler ve uygulamalar aracılığıyla sağlık çalışanları üzerinde iletişim ve güven gibi olgularla ilgili olarak bazı olumsuz etkiler bıraktığı tahmin edilmektedir. Özel hastanelerden de veri toplanabilirse, örgütsel güven, empati ve iletişim çatışmaları arasındaki etkileşime ilişkin daha sağlam ve gerçeğe daha yakın bulgulara erişilmesi mümkündür. Buna bağlı olarak, farklı sonuçların ortaya çıkması olasıdır. Ayrıca, kamu özel sektör karşılaştırması da yapılarak, ortak noktalar ile farklı noktalar belirlenebilecektir.

Zamana ve bütçeye ilişkin yetersizlikler, araştırmanın sağlık sektörüyle sınırlı kalmasına neden olmuştur. Diğer sektörlerden de veri toplanması halinde özgün değeri daha güçlü eserlerin ortaya çıkarılması mümkün olabilecektir.

Araştırmanın kapsamında hastaların ve hasta yakınlarının bakış açıları yer almamaktadır. Hizmet sunanlarla birlikte sağlık hizmetinden faydalanan hastaların da katılımıyla, çalışanların hizmet sunarken sergiledikleri empati eğilimleri, empati becerileri ve iletişim çatışmaları, benzer araştırma modellerinde ele alınarak çift yönlü ölçüm ve kıyaslama yapılabilecektir.

Sağlık sektörünün çalışma koşullarındaki yoğunluk, zaman kisitını ortaya çıkarmaktadır. $\mathrm{Bu}$ nedenle sadece anket yöntemiyle veri toplanabilmiştir. Görüşme ve gözlem gibi farklı veri toplama yöntemlerinden yararlanarak verilerin zenginleştirilmesi mümkün olamamıştır. Aynı araştırma sorusunun, nitel ve nicel tekniklerin birbirlerini desteklediği karma bir desenli bir tasarımla tekrar ele alınması durumunda özgünlük açısından çok daha sağlam temellere dayanacağı düşünülmektedir.

Veri toplama işlemine iki aylık süre ayrılabildiği için örneklem hacmi genişletilememiştir. Zaman aralığının genişletilebilmesi halinde, örneklem hacmi genişletilebilecektir. Dolayısıyla örnekleme hatası da düşürüleceği için tahminlerdeki isabet oranlarının yükselmesi sağlanabilecektir.

Daha sonra yapılacak çalışmalarla ilgili öneriler şöyle sıralanabilir:

- Araştırma sadece Elazığ ili kamu hastaneleri ile sınırlı kalmaktadır. Sonraki 
çalışmalar kamu ve özel hastaneler olmak üzere farklı iller ve bölge veya daha geniş bölgeleri kapsayacak şekilde desteklenmelidir.

- Araştırma kurum izni alınamayan özel sağlık kuruluşları gönüllük kapsamında veri toplama işlemi genişletilmelidir.

- Zaman kısitlılığ1 ve iş yoğunluğu nedeni ile araştırma kapsamına giremeyen sağlık çalışanlarının kapsamı genişletilmelidir.

- Sağlık çalışanları dışında hastalar üzerinde de benzer çalışmalar ve analizler yapılabilir.
- Araştırmadaki demografik özellikler ile diğer değişkenlerle analizi yapılıp yeni bir bakış açısı kazandırılabilir.

- Araştırma üç değişkenli şekilde yapılmış alt boyutları karşılaştırılmıştır. Daha kapsamlı değişkenler ve farklı ölçekler kullanılarak desteklenmelidir.

- Literatürde bu çalışma ile ilgili az sayıda araştırma olduğundan farklı sektörlerde ve kurumlarda benzer nitelikte çalışmaların varlığı konu ile ilgili kapsamı genişletecektir.

\section{KAYNAKLAR}

1. Mckenna, E. (2000). "Business Psychology and Organisational Behaviour". USA/Philadelphia: Psychologypress Ltd., 390420.

2. Koçel, T. (2015). İşletme Yöneticiliği (16. Baskı). İstanbul: Beta Yayınları.

3. Türnüklü, A. (2006). "Sınıf ve Okul Disiplinine Cağdaș Bir Yaklaşım: Onarıcı Disiplin”. Ankara: Ekinoks Yayınevi.

4. Karip, E. (2003). Çatışma Yönetimi. Ankara: Pegem Yayıncilık.

5. Gross, M.A. and Guerrero, L.K. (2000). "Managing Conflict Appropriately and Effectively: An Application of the Competence Model to Rahim's Organizational Conflict Styles". The International Journal of Conflict Management, 11 (3), 200-226

6. Nasello, J.A. and Triffaux, J.M. (2020). "Focusing: A New Challenger for Improving The Empathy Skills of Medical Students". Complementary Therapies in Medicine, 53, 1-6.

7. Cannity, K.M, Banerjee, S.C, Hichenberg, S, Leon-Nastasi, AD, Howell, F, Coyle, N, Zaider, T. and Parker, P.A. (2021) "Acceptability and Efficacy of A Communication Skills Training for Nursing Students: Building Empathy and Discussing Complex Situations". Nurse Education in Practice, 50, 1-7.

8. Şahin, F.S, Nergüz, B.S. and Serin, O. (2011) "Effect of Conflict Resolution and Peer Mediation Training on Empathy Skills". Procedia Social and Behavioral Sciences, 15, 23242328.

9. Basar, G, Akın, S. ve Durna, Z. (2015). "Hemşirelerde ve Hemşirelik Öğrencilerinde Problem Çözme ve İletişim Becerilerinin Değerlendirilmesi”. Gümüşhane Üniversitesi Sağlık Bilimleri Dergisi, 4819, 125-147.

10. Çingöl, N, Karakaş, M, Çelebi, E. and Zengin, S. (2021) "Determining The Effect of An Intercultural Nursing Course on Empathic Skill and Intercultural Sensitivity Levels: An Intervention Study". Nurse Education Today, 99, 1-9.

11. Erol, S, Aygün, S. ve Çay, H. (2018). "Birinci Basamak Sağlık Çalışanlarında Duygusal Zekâ, Benlik Saygısı ve İlişkili Faktörler". Gümüşhane Üniversitesi Sağlık Bilimleri Dergisi, 7 (2), $10-20$.

12. Hudnall, J.A. and Kopecky, K.E. (2020). "The Empathy Project: A Skills-Development Game Innovations in Empathy Development". Journal of Pain and Symptom Management, 60 (1), 164-172.

13. Ağaçdiken, S. ve Aydoğan, A. (2017). "Hemşirelerde Empatik Beceri ve Etik Duyarlılık İlişkisi”. Gümüşhane Üniversitesi Sağlık Bilimleri Dergisi, 6 (2), 122-129.

14. Mindek, N. (1984). An Evaluation of Determinants of Interpersonal Trut in Task Groups. Doktora Tezi, Boğaziçi Üniversitesi Sosyal Bilimler Enstitüsü, İstanbul.

15. Korczynski, M. (2003). Güvenin Ekonomi Politiği. (Çev: Ş. Erdem). Içinde: Erdem, F. (Ed.). "Sosyal Bilimlerde Güven". Ankara: Vadi Yayınları.
16. Gilbert, J.A. and Tang, T.L. (1998). An Examination of Organizational Trust Antecedents. Public Personnel Management, 27 (3), 321-338.

17. Ülker, G. (2008). "Çalışanların Örgütsel Adalet Algılamalarının Yönetici Ve Örgüte Duyulan Güven Üzerindeki Etkisi”. Abant İzzet Baysal Üniversitesi Sosyal Bilimler Enstitüsü Dergisi, 1 (16), 188-208.

18. Seçer, H.S. (2009). "Profesyonel Mesleklere ve Profesyonel Bireylere Güven". Kamu-İş Dergisi, 10 (4), 247-277.

19. Paliszkiewicz, J, Koohang, A. and Nord, J.H. (2014) "Management Trust, Organizational Trust, and Organizational Performance: Empirical Validation of An Instrument". Online Journal of Applied Knowledge Management, 2 (1), 28-39.

20. Akgündüz, Y. ve Güzel, T. (2014). "Örgütsel Adalet ile Örgütsel Bağlılık Arasındaki İlişkide Örgütsel Güvenin Aracılık Etkisi”. Anadolu Üniversitesi Sosyal Bilimler Dergisi, 14 (3), 1-17.

21. Ensari, M.S. ve Karabay, M.E. (2016). "The Mediating Effect of Perceived Ethical Climate on Organizational Commitment, Trust and Turnover Intention Interactions: A Research on Insurance Sector". European Journal of Business and Social Sciences, 5 (1), 47-63.

22. Firth-Cozens, J. (2004). "Organisational Trust: The Keystone to Patient Safety". Quality and Safety in Health Care, 13 (1), 5661.

23. Hall, M, Dogan, E, Zheng, B. and Mishra, A. (2001). "Trust in Physicians and Medical Institutions. Does it Matter?". The Milbank Quarterly, 79 (4), 613-639.

24. Çokluk, B.Ö. ve Yılmaz, K. (2008). "İlköğretim Okullarında Örgütsel Güven Hakkında Öğretmen Görüşleri”. Kuram ve Uygulamada Eğitim Yönetimi, 54, 211-233.

25. Erdal, N. (2020). Sağlık Çalışanlarında Örgütsel Güven ve Örgütsel Vatandaşlığın İs Tatmini Üzerindeki Etkilerinin İncelenmesi: Bir Üniversite Hastanesi Örneği. Doktora Tezi, Beykent Üniversitesi Lisansüstü Eğitim Enstitüsü, Ankara.

26. Gürbüz, S. ve Şahin, F. (2016). Sosyal Bilimlerde Araștırma Yöntemleri. Ankara: Seçkin Yayıncılık.

27. Baş, T. (2008). Anket. Ankara: Seçkin Yayıncılık.

28. Düşükcan, M. (2003). Örgütlerde Çatışma ve Çatışma Yönetimi Sürecinde Örgütsel İletişim Etkililiğii: Kuramsal ve Uygulamalı Bir Çalıșma. Doktora Tezi, Selçuk Üniversitesi Sosyal Bilimler Enstitüsü, Konya.

29. Dökmen, Ü. (1988). "Empatinin Yeni Bir Modele Dayandırılarak Ölçülmesi ve Psikodrama ile Geliştirilmesi". Ankara Üniversitesi, Eğitim Bilimleri Fakültesi Dergisi, 1-2 (21), 155-190.

30. Tokgöz, E. ve Seymen, O.A. (2013). "Örgütsel Güven, Örgütsel Özdeșleșme Ve Örgütsel Vatandaşlık Davranıșı Arasındaki İlişki: Bir Devlet Hastanesinde Araştırma”. Öneri Dergisi, 10 (39), 61-76.

31. Sencan, H. (2005). Sosyal ve Davranıșsal Ölçümlerde Güvenilirlik ve Geçerlilik. Ankara: Seçkin Yayınevi.

32. Büyüköztürk, S. (2012). SPSS ile Veri Analizi El Kitabı. 
Ankara: Pegem A Yayınevi.

33. Gürbüz, S. (2019). Sosyal Bilimlerde Arac1, Düzenleyici ve Durumsal Etki Analizleri. Ankara: Seçkin Yayıncılık.

34. Rehber, E. ve Atıcı, M. (2009). "İlköğretim İkinci Kademe Öğrencilerinin Empatik Eğilim Düzeylerine Göre Çatışma Çözme Davranışlarının İncelenmesi”. Çukurova Üniversitesi Sosyal Bilimler Enstitüsü Dergisi. 18(1), 323-342.

35. Karahan, T.F, Sardoğan, M.E, Güven, M.Ç, Özkamalı, E. ve Dicle, A.N. (2006). "İ̉nsan İlişkileri ve İletişim Dersi'nin Öğretmen Adaylarının Çatışma Çözme ve Empatik Beceri Düzeylerine Etkisi”. Eurasian Journal of Educational Research. 23, 127-136

36. Taşkın, E, Düger, Y.S, Söylemez, C, Boz, D ve Polat, F (2014). "İlişkisel Pazarlamada İletişim, Güven ve Empati
Boyutları ve Özel Eğitim Kurumlarında Bir Uygulama: Kütahya İl Merkezi Örneği”. Dumlupınar Üniversitesi Sosyal Bilimler Dergisi, Kütahya Özel Sayısı, 7-12.

37. Akca, M. (2017). "The Impact of Toxic Leadership on Intention to Leave of Employees". International Journal of Economics, Business and Management Research, 1 (4), 285-298.

38. Alrashid, S.A.A. (2020). "Conflict Management in Ethnic Tension Zones: Sport Contribution in Co-existence and Inclusion Citizenship Diversity: A Case Study in Aleksandria”. American Journal of Sports Science, 8 (4), 99-104

39. Dökmen, Ü. (2008). Sanatta ve Günlük Yaşamda İletişim Çatışmaları ve Empati. İstanbul: Remzi Kitabevi. 